\title{
THE DILEMMA CAUSED BY DELUSIONAL DEFENDANTS
}

\author{
Hon Justice David Collins*
}

This article explains the dilemmas that arise when a defendant, who is prone to delusional episodes but nevertheless fit to stand trial, elects to exercise the right to represent themself. It examines the background to the criteria for determining if a defendant is fit to stand trial under the Criminal Procedure (Mentally Impaired Persons) Act 2003, and then analyses the way those criteria have been interpreted in New Zealand. The difficulties caused by the New Zealand approach are then analysed in more detail by reference to the leading 2008 Supreme Court case of Cumming v R, which involved a delusional defendant who represented himself and who was subsequently found to have been unfit to stand trial.

\section{INTRODUCTION}

A determination that a defendant has the mental capacity to stand trial is a judicial decision that is informed by medical evidence. ${ }^{1}$ Unfortunately, while the law and medicine interact when decisions about a defendant's mental capacity arise, the two disciplines are not always synchronised. As a consequence, judges applying statutory and common law concepts when determining if a defendant has the mental capacity to stand trial can reach conclusions that do not fit comfortably with medical views. The reason for this paradox is understandable. Medical science continues to develop at a pace which vastly exceeds the development of legislation and common law principles. As a result, the understanding that psychiatrists and psychologists have about an individual's mental capacity is often difficult to reconcile with statutory and common law concepts which ultimately determine if a defendant is fit to stand trial.

This article explains the dilemmas that arise when a defendant, who is prone to delusional episodes but nevertheless fit to stand trial, elects to exercise his or her right to represent themself.

* High Court of New Zealand. Honorary Fellow, Victoria University Wellington Faculty of Law. It is a pleasure to contribute to this edition of the Victoria University of Wellington Law Review, published in honour of Professor Atkin. It was my privilege to teach LLB(Hons) and LLM classes with Professor Atkin, who has made a wonderful contribution to research and teaching in a number of branches of law which are socially significant.

$1 \quad R v$ Rivett (1950) $34 \mathrm{Cr}$ App R 87. 
Thankfully this is a scenario that arises only occasionally. However, when such cases do arise they generate significant challenges for judges, lawyers and health professionals. Such cases also involve the weighing of difficult, and at times conflicting, considerations.

In order to explore the issues raised by this scenario, this article shall examine the background to the current legislative criteria for determining if a defendant is fit to stand trial and then analyse the way those criteria have been interpreted in New Zealand. The difficulties caused by the New Zealand approach are then analysed in more detail by reference to the leading reported case involving a delusional defendant who represented himself and who was subsequently found to have been unfit to stand trial. ${ }^{2}$

\section{THE CRITERIA FOR ASSESSING FITNESS TO STAND TRIAL}

\section{A Background}

The acknowledgement a defendant may not be culpable of a crime because of his or her impaired mental capacity can be traced to Greek mythology. Heracles ${ }^{3}$ is said to have killed his wife and three children when cursed by the goddess Hera. Despite the homicides being witnessed by many townspeople, Heracles was declared not liable because of his mental impairment. Heracles was given care and treatment which included counselling to prevent him taking his own life when he recovered his mental capacity and realised what he had done. ${ }^{4}$

\section{B Common Law}

The common law criteria for fitness to stand trial were explained in $R v$ Pritchard, a case involving the fitness of a deaf mute to stand trial, who was charged with a capital offence. ${ }^{5}$ Alderson B instructed the jury: ${ }^{6}$

There are three points to be inquired into: - first, whether the prisoner is mute of malice or not; secondly, whether he can plead to the indictment or not; thirdly, whether he is of sufficient intellect to comprehend the course of the proceedings on the trial so as to make a proper defence - to know that he might challenge any of you to whom he may object - and to comprehend the details of the evidence, which in a case of this nature must constitute a minute investigation.

2 Cumming $v R$ [2008] NZSC 39, [2010] 2 NZLR 433.

3 Greek name Heracles; Roman name Hercules.

4 Edith Hamilton Mythology: Timeless Tales of Gods and Heroes (Little, Brown and Co, New York, 1942) at 229-230.

$5 \quad R v$ Pritchard (1836) 7 C \& P 303.

6 At 304 (emphasis added). 
The Pritchard requirements for being unfit to stand trial were subsequently approved and expanded upon so that the common law ultimately identified five criteria for fitness to stand trial; namely, that the defendant had the ability to: ${ }^{7}$

(1) plead to the indictment;

(2) understand the course of the proceedings;

(3) instruct a lawyer;

(4) challenge a juror; and

(5) understand the evidence.

In $R v$ Robertson the Court of Appeal of England and Wales revisited the criteria for determining if a defendant was unfit to stand trial by reason of mental disability. ${ }^{8}$ That case concerned a defendant charged with murder, who dismissed his lawyers before trial. A jury was asked to determine prior to the trial if the defendant was suffering a disability within the meaning of s 4 of the Criminal Procedure (Insanity) Act 1964 (UK). ${ }^{9}$ This issue arose because of concerns that the defendant was suffering persecution delusions which might affect his ability to make rational decisions when conducting his defence. The jury concluded the defendant was suffering a disability and he was committed to a mental institution, after which the Crown appealed on the grounds that the defendant was not unfit to stand trial simply because he suffered delusions "which at any moment might interfere with proper action on his part". ${ }^{10}$ The Court of Appeal agreed. Lord Parker adopted the quotation from Pritchard set out above. He then said the determination the defendant was not fit to stand trial was unsatisfactory because: ${ }^{11}$

... the jury may have thought that the mere fact [the defendant] was not capable of doing things which

were in his best interests was sufficient to enable them to return [the] finding of disability.

Robertson is the source of the view that at common law, the fact a defendant acts irrationally when defending himself or herself because of a mental disability is not in itself grounds for concluding he or she is unfit to stand trial.

$7 \quad R v$ Berry (1876) 1 QBD 447; $R$ v Sharp [1957] 1 QB 552; and $R v$ Padola [1960] 1 QB 325 (CA).

$8 \quad R v$ Robertson [1967] 1 WLR 1767 (CA).

9 Criminal Procedure (Insanity) Act 1964, s 4(1): "This section applies where on the trial of a person the question arises (at the instance of the defence or otherwise) whether the accused is under a disability, that is to say under any disability such that apart from this Act would constitute a bar to his being tried ...".

$10 R v$ Robertson, above $\mathrm{n} 8$, at 1773.

11 At 1773. 
The approach taken in Robertson can be compared with the course followed by the United States Supreme Court eight years earlier. In Dusky v United States, the Supreme Court said the test as to whether a defendant was fit to stand trial must include an assessment of whether he or she: ${ }^{12}$

has sufficient present ability to consult with his [or her] lawyer with a reasonable degree of rational understanding - and whether he [or she] has a rational as well as factual understanding of the proceedings against him [or her].

\section{Legislation}

New Zealand's legislative regime governing a defendant's fitness to stand trial can be traced to $\mathrm{s}$ 32 of the Mental Defectives Act 1911. Under that legislation a defendant who could not plead to an indictment by reason of insanity was ordered to be held in such "institution, prison, or place of confinement as the Court [seemed] fit, until the pleasure of the Minister of Justice [was] known". In 1957 the procedure for determining if a defendant was not able to be tried by reason of insanity was changed so that the determination of insanity could only be made by a High Court judge based on the evidence of two medical practitioners. ${ }^{13}$

In 1969 the legislation relating to a defendant's fitness to stand trial was incorporated into the Criminal Justice Act 1954. That Act was amended by the Criminal Justice Amendment Act 1969 which introduced a new regime for a judge of the High Court to determine if a defendant was not able to stand trial by reason of him or her being "under a disability". The term "under a disability" was defined to mean: ${ }^{14}$

... mentally disordered to such an extent as to be unable to plead, or unable to conduct a defence or

instruct a solicitor for that purpose, or unable to comprehend the course of the proceedings.

"Mentally disordered" had the same meaning as in the Mental Health Act 1969. A person found to be under a disability was automatically detained in a hospital as a special patient under the Mental Health Act 1969. ${ }^{15}$ The Criminal Justice Amendment Act 1969 adopted some of the provisions of the Criminal Procedure (Insanity) Act 1964 (UK). ${ }^{16}$

The 1969 amendments to the Criminal Justice Act 1954 were substantially reproduced in s 108 of the Criminal Justice Act 1985. Thus, under s 108 of the Criminal Justice Act 1985, a defendant would be unfit to stand trial if he or she was found to be mentally disordered to such an extent that he or she was unable to:

12 Dusky v United States 362 US 402 (1960) at 403.

13 Mental Health Amendment Act 1957, s 5.

14 Criminal Justice Amendment Act 1969, s 2(39A).

15 Section 2(39G).

16 (3 June 1969) 360 NZPD 457-459. 
(1) plead;

(2) understand the nature or purpose of the proceeding; or

(3) communicate adequately with counsel for the purposes of conducting a defence.

In 1992 the Criminal Justice Act 1985 was amended so that, from the time of that amendment, "mentally disordered" had the same meaning as in the Mental Health (Compulsory Assessment and Treatment) Act 1992 (the Mental Health Act).

The criteria to be under a disability in s 108 of the Criminal Justice Act 1985 were interpreted consistently with the common law requirements to be unfit to stand trial. This was illustrated in $R v$ Power $^{17}$ where the Court of Appeal adopted the approach of the Court of Appeal of England and Wales in Robertson. The Court of Appeal said in Power that the test under s 108 of the Criminal Justice Act 1985:18

... did not require that the [defendant] actually give instructions which [were] in his or her best interests

A high threshold of fitness, including a best interests component, would derogate from the fundamental principle that accused persons are entitled to choose their own defences and to present them as they choose.

The reference to a "high threshold" in Power meant that a defendant with a low level of competence could be fit to stand trial.

The Criminal Procedure (Mentally Impaired Persons) Act 2003 (the Act) introduced a new regime for determining if a defendant is fit to stand trial. Section 4 of that Act defines "unfit to stand trial" in the following way:

(a) ... a defendant who is unable, due to mental impairment, to conduct a defence or to instruct counsel to do so; and

(b) includes a defendant who, due to mental impairment, is unable-

(i) to plead:

(ii) to adequately understand the nature or purpose or possible consequences of the proceedings:

(iii) to communicate adequately with counsel for the purposes of conducting a defence.

The definition of "unfit to stand trial" in s 4 of the Act was the product of changes contained in a Supplementary Order Paper introduced during the passage of the legislation. The definition of "unfit to stand trial" changed the criteria to be unfit to stand trial in four key ways.

$17 R v$ Power CA187/96, 22 October 1996.

18 At 8. 
First, the precondition for finding a defendant unfit to stand trial was changed from a diagnosis of mental disorder to a finding of mental impairment. The drafters of the Act wanted to remove the need for a determination that a defendant was mentally disordered as a precondition to him or her being unfit to stand trial. ${ }^{19}$ They appreciated that the definition of "mentally disordered" in s 108 of the Criminal Justice Act 1985 did not encompass those whose mental impairment was solely attributable to intellectual disabilities. The drafters of the Act were concerned to ensure that persons with intellectual disabilities were not forced to stand trial in circumstances where they would have been found to have been unfit to stand trial had they been diagnosed as suffering from a mental disorder.

Secondly, the definition of "unfit to stand trial" identifies an unfit defendant as one who, because of mental impairment, is "unable to conduct a defence or to instruct counsel to do so". This criterion is similar to the common law criteria for unfitness to stand trial which eschewed notions of comprehension and rationality.

Thirdly, the inquiry into a person's fitness to stand trial is not limited to the three capacities which a defendant must have. The insertion of "includes" at the commencement of subpara (b) of the definition of "unfit to stand trial" in the Act means that the inquiry into a person's fitness to stand trial can go beyond the three capacities identified in subpara (b)(i)-(iii) of the definition of "unfit to stand trial".

Fourthly, the qualifier "adequately" in subparagraph (b)(ii) and (iii) of the definition of "unfit to stand trial" is extended to the inquiry into a defendant's ability to understand the nature, purpose or possible consequence of the proceedings.

The Act prevents a court from making a finding of unfitness to stand trial unless it is satisfied on the balance of probabilities that the evidence against the defendant is sufficient to establish that he or she caused the act or omission that forms the basis of the offence with which the defendant is charged. ${ }^{20}$ If the court is satisfied that the defendant caused the act or omission that forms the basis of the offence, it must then determine whether or not the defendant is mentally impaired and, if so, whether or not he or she is unfit to stand trial. ${ }^{21}$ When assessing whether or not the defendant is unfit to stand trial, the court must receive the evidence of two health assessors. ${ }^{22}$ If the court is satisfied that the defendant is mentally impaired, the court must record a finding to that effect. The court must then decide whether the defendant is unfit to stand trial after giving the parties the

19 (5 October 1999) 580 NZPD 19706

20 Criminal Procedure (Mentally Impaired Persons) Act 2003, s 9.

21 Section 14

22 "Health assessor" is defined in s 4 as a "practising psychiatrist who is registered as a medical practitioner; or a psychologist; or a specialist assessor under the Intellectual Disability (Compulsory Care and Rehabilitation) Act 2003". 
opportunity to call evidence and make submissions on this issue. A defendant who has been found unfit to stand trial may be detained in a hospital as a "special patient" or in a secure facility as a "special care recipient" under the Intellectual Disability (Compulsory Care and Rehabilitation) Act $2003 .^{23}$ Less intrusive orders are set out in s 25 of the Act.

\section{Case Law}

In November $2006 \mathrm{Mr}$ Roberts went on trial for murdering his partner. It was alleged he had killed his partner by dropping a concrete block on her head several times. Mr Roberts gave evidence, contrary to the advice of his lawyer and Fogarty J. Mr Roberts' evidence was so unusual that Fogarty $\mathrm{J}$ thought he was delusional and that he might not have been able to instruct his counsel. Fogarty $\mathbf{J}$ stopped the trial and ordered psychiatric reports to assist him in determining if Mr Roberts was unfit to stand trial by reason of mental impairment. In his judgment, Fogarty J suggested that the test of mental impairment might incorporate an assessment of whether the accused was fit to make decisions in his own interests as to the conduct of the trial, and that the question was whether or not Mr Roberts was "unable, due to mental impairment, to conduct a [rational] defence or to instruct counsel to do so". ${ }^{24}$ If this approach were correct it would mean that Power no longer accurately reflected the law in relation to fitness to stand trial and that a defendant's "decisional competence" could form part of the assessment under s 4 of the Act. ${ }^{25}$

Any suggestion the test of "unfitness to stand trial" incorporated an assessment of a defendant's "decisional competence" was, however, quashed by the Court of Appeal in Solicitor-General v Dougherty. ${ }^{26}$ That case concerned a defendant who was charged with 74 counts of filing false GST returns. He formed the view that the Inland Revenue Department persecuted people including him, with the intention of forcing them to commit suicide. Psychiatric evidence established that while $\mathrm{Mr}$ Dougherty was delusional, he was nevertheless able to conduct a defence. However, the trial Judge concluded Mr Dougherty's delusional disorder affected his perception of the charges to such an extent that he was unable to instruct counsel and therefore not fit to stand trial. The SolicitorGeneral appealed.

In its judgment the Court of Appeal said that it was: ${ }^{27}$

23 Intellectual Disability (Compulsory Care and Rehabilitation) Act 2003, s 89.

$24 R v$ Roberts (No 2) HC Auckland CRI-2005-092-014492, 22 November 2006 at [57] (in the original text).

25 Other cases which raised questions about the continued effect of Power after the passing of the Act include $S v$ Police HC Palmerston North CRI-2005-454-000047, 8 December 2005 at [23]; and P v Police [2007] 2 NZLR 528 (HC) at [20]-[23].

26 Solicitor-General v Dougherty [2012] NZCA 405, [2012] 3 NZLR 586.

27 At [40]. 
... satisfied that there is no discernible statutory intention to move away from the settled principle that fitness to plead does not include an inquiry into whether the accused will act in his or her best interests. We accept that the new drafting structure allows scope for consideration of a wider range of factors than previously might have been the case. But there is no statutory support for a change in relation to decisional competence, and we do not consider the Courts should implement one.

The Court of Appeal was satisfied there was no suggestion in the definition of "unfit to stand trial" in the Act which indicated Parliament had departed from that part of Power that stressed an accused's right to defend himself or herself as he or she chose. In its judgment the Court of Appeal distanced itself from the approach taken by Fogarty $\mathrm{J}$ in Roberts, which it construed as meaning that an inquiry into whether a defendant could conduct a rational defence involved an assessment of a defendant's decisional competence or his or her ability to make a decision in his or her best interests. The Court of Appeal's rejection of any inquiry into a defendant's ability to conduct a rational defence was reached in the context of the Court's conclusion that a defendant's decisional competence and ability to make decisions in his or best interests was an irrelevant consideration. ${ }^{28}$

\section{THE CUMMING CASE}

Mr Cumming's alleged offending pre-dated the Act. Although his fitness to plead was assessed under s 108 of the Criminal Justice Act 1985, his case demonstrates the challenges faced by judges, lawyers, witnesses and medical practitioners when a defendant who is suffering from delusions insists on representing himself.

Mr Cumming was charged with committing a number of sexual and violent crimes against his former girlfriend who was 16 at the time of the alleged offending. The charges brought against $\mathrm{Mr}$ Cumming included sexual violation by rape, abduction for sex and assault with a weapon. It was alleged Mr Cumming restrained his former girlfriend in his flat by locking the doors and windows and chaining her ankles. He would not allow her to go to the toilet at night and he would sometimes tie her hands behind her back and gag her. The Crown alleged Mr Cumming made extreme sexual demands of his former girlfriend, which she only acceded to because she was scared of him. There were also allegations Mr Cumming violently assaulted his former girlfriend.

Prior to being tried in November 2002 Mr Cumming was assessed by two psychiatrists, who concluded he displayed a severe personality disorder with anti-social narcissistic and paranoid features. It was nevertheless determined he was fit to stand trial. Mr Cumming pleaded not guilty and dismissed all lawyers who were appointed to represent him. One of the dismissed lawyers was appointed amicus to assist Mr Cumming when it became apparent he was intending to represent himself.

28 Solicitor-General v Dougherty, above n 26, at [12]-[13] and [40]. 
During the trial Mr Cumming cross-examined his former girlfriend for over a day. His crossexamination was highly repetitive, unstructured and often dwelt on irrelevant matters. ${ }^{29} \mathrm{Mr}$ Cumming's performance caused the jury to send a note to the trial Judge which asked: ${ }^{30}$

How come this is a fair trial? At least some of us are seriously troubled to be asked to make decisions

from such a lopsided presentation, especially given the high stakes.

The trial Judge told the jury that Mr Cumming had a right to represent himself, that one of his previous lawyers had been appointed as amicus to assist Mr Cumming, that the jury had to decide the case on the evidence that it heard in court and that if there were concerns about the fairness of Mr Cumming's trial he could raise those concerns with the Court of Appeal if he were convicted. ${ }^{31}$

Mr Cumming was convicted and sentenced to preventive detention. He appealed both his conviction and sentence. He was represented by counsel in the Court of Appeal.

It was accepted on behalf of Mr Cumming in the Court of Appeal that he did not satisfy the criteria in s 108 of the Criminal Justice Act 1985 and that he was fit to stand trial. The Court of Appeal was also satisfied he was able to plead, to understand the nature and purpose of the proceedings, and that he would have been able to communicate adequately with counsel for the purpose of conducting his defence if he had not decided to represent himself.

The case for Mr Cumming in the Court of Appeal was advanced on the basis his mental, psychological, personality and intellectual problems precluded him from being able to represent himself at the trial, and that as a consequence he was denied the right to a fair trial guaranteed by $\mathrm{s}$ 25(a) of the New Zealand Bill of Rights Act 1990 (NZBORA).

There was a sound, factual basis for the approach taken on Mr Cumming's behalf in the Court of Appeal where it was submitted he conducted his case in a way which demonstrated he had no appreciation of how implausible his defence was or how he damaged his own case by the way he conducted himself.

The Court of Appeal dismissed Mr Cumming's appeal against his conviction and sentence. In doing so, the Court of Appeal assessed whether his exercise of his right to represent himself ${ }^{32}$ compromised his right to a fair trial. The Court of Appeal concluded that Mr Cumming's decision to

29 Mr Cumming's trial pre-dated s 95 of the Evidence Act 2006 which now prohibits a defendant in a criminal proceeding that alleges sexual offending, domestic violence or harassment from personally cross-examining the complainant or a child who is a witness, unless the judge gives the defendant permission to crossexamine a child witness.

30 Cumming $v R$, above $\mathrm{n} 2$, at [3].

31 At [4].

32 Crimes Act 1961, s 354 now repealed and replaced with Criminal Procedure Act 2011, s 11. 
represent himself was fully informed and deliberate ${ }^{33}$ and that his right to represent himself could not outweigh concerns that in representing himself Mr Cumming failed to act in his best interests. The Court of Appeal reasoned that primacy could not be given to concerns Mr Cumming did not act in his best interests because that would derogate from the right of a defendant to choose and present his or her defence as he or she sees fit, consistent with a defendant's right to autonomy and selfdignity. ${ }^{34}$ The Court of Appeal was satisfied Mr Cumming was not denied a fair trial because he had been allowed to present his defence.

Mr Cumming was granted leave to appeal to the Supreme Court, where his convictions and sentence were quashed. The Supreme Court received further medical evidence which satisfied it that Mr Cumming was suffering from a profound mental disorder at the time of his trial and that as a consequence, he was under a disability of such a nature that he was unfit to stand trial. The Supreme Court therefore concluded that there had been a substantial miscarriage of justice. Part of the evidence relied upon by the Supreme Court included testimony from one of Mr Cumming's former treating psychiatrists, who said: ${ }^{35}$

\footnotetext{
As Mr Cumming was acting as his own counsel the impact of his mental disorder was even greater upon his functioning in court. Conducting a delusionally based defence and with obvious impairments in his ability to process information, make appropriate inquiries and respond to what was happening, Mr Cumming, as his own counsel, could be said to be unable to communicate adequately with himself. Essentially both defendant and counsel were mentally disordered in this situation.
}

The Supreme Court ordered a retrial.

Mr Cumming has not yet been retried. In May 2010 the High Court found Mr Cumming was not fit to stand trial at which point he was made a special patient pursuant to s 24(2)(a) of the Act. In September 2013 the Mental Health Review Tribunal determined Mr Cumming was no longer unfit to stand trial. ${ }^{36}$ This finding led to the Attorney-General issuing a direction on 21 October 2013 that Mr Cumming be brought before the High Court. ${ }^{37}$ Thereafter, Mr Cumming was remanded in custody for re-trial. However, on 18 December 2013 Mr Cumming was found to be mentally disordered under the Mental Health Act. MrCumming is currently subject to a compulsory treatment order under the Mental Health Act but he is also still currently considered to be fit to stand trial.

$33 R v$ Miers (1994) 11 CRNZ 307 (CA) at 310.

34 McKaskle v Wiggins 456 US 168 (1984); Illinois v Allen 397 US 337 (1970); and Rv Swain (1991) 63 CCC $3 \mathrm{~d} 481$.

35 Cumming $\vee R$, above $\mathrm{n} 2$, at [20].

36 Mental Health (Compulsory Assessment and Treatment) Act 1992, s 80(4)(a).

37 Criminal Procedure (Mentally Impaired Persons) Act 2003, s 31(2)(a). 
On 7 July 2014 the High Court dismissed an application brought by Mr Cumming to have his prosecution stayed on the grounds of delay and abuse of process. ${ }^{38}$

\section{ANALYSIS}

Mr Cumming's case highlights a number of issues with the way in which assessments are made, prospectively, about the fitness of delusional defendants to stand trial. Those issues are now addressed under the following headings:

(1) the threshold for being unfit to stand trial;

(2) mentally disordered patients;

(3) the right to self-representation; and

(4) the interests of justice.

\section{A The Threshold for Being Unfit to Stand Trial}

The Court of Appeal was undoubtedly correct when it said in Dougherty that an inquiry into a defendant's fitness to stand trial cannot include an assessment of his or her ability to make decisions that are in his or her best interests. Even proponents of the view that s 4 of the Act should accommodate a defendant's "best interests" inquiry appear to accept that the text of the definition of "fitness to stand trial" does not actually allow an assessment of a defendant's ability to make a decision in his or her best interests. ${ }^{39}$ This view is reinforced by an examination of the legislative history to the definition of "unfit to stand trial" in s 4 of the Act. The original proposed definition was amended by a Supplementary Order Paper. The explanatory note to the Supplementary Order Paper said that the proposed definition of "unfit to stand trial" was to be amended to exclude from the definition defendants who, due to mental impairment, were unable to make an informed decision about whether or not they should give evidence. ${ }^{40}$

Less straightforward is the Court of Appeal's apparent rejection of any inquiry into a defendant's ability to make rational decisions. The Court of Appeal in Dougherty appears to have conflated an assessment of the defendant's ability to make rational decisions with his or her ability to make decisions that are in his or her best interests. The two concepts are different. Defendants frequently make decisions in the course of a trial that are not in their best interests, but they may do so for rational reasons, or in circumstances where there can be no doubt they are rational.

$38 \quad R v$ Cumming [2014] NZHC 1576.

39 Warren Brookbanks Competencies of Trial: Fitness to Plead in New Zealand (LexisNexis, Wellington, 2011) at [4.7].

40 Supplementary Order Paper (161) 2003 Criminal Justice Amendment Bill (No 7) 1999 (328-1) (explanatory note). 
In the context of s 4 of the Act, an inquiry into a defendant's ability to rationally make decisions might focus upon whether he or she is engaged in bizarre thinking associated with decision-making that impugns the integrity of the trial process. ${ }^{41}$

It is at least arguable however, the presence of the adverb "adequately" in subpara (b)(ii) of the definition of "unfit to plead" in s 4 of the Act opens the possibility for an inquiry to be made into the rationality of a defendant's decision making. An assessment of the adequacy of a defendant's ability to understand the nature, purpose and consequence of criminal proceedings provides room for an inquiry into the defendant's ability to rationally understand the proceedings. If this approach is correct it would be permissible for a court to conclude that a delusional defendant who has an irrational understanding of proceedings probably does not have an adequate understanding of the proceedings and is therefore unfit to stand trial.

This approach is similar to the test articulated by Alderson B in Pritchard when he explained that when assessing the fitness of a defendant to stand trial the jury needed to be satisfied he or she had "sufficient intellect" to make a "proper defence". ${ }^{42}$ It is also similar to the approach that has worked effectively in the United States since the Supreme Court's decision in Dusky, which held that an assessment of a defendant's rationality was an integral component of an evaluation of his or her fitness to stand trial.

Had this approach been taken at the time Mr Cumming was assessed as being fit to stand trial in 2002, there is a real possibility he would have been found unfit to stand trial under s 108 of the Criminal Justice Act 1985 on the grounds that he was unable to communicate adequately with counsel for the purposes of conducting a defence. Although it is now impossible to predict with any certainty what might have happened had Mr Cumming been found unfit to stand trial from the outset, it can be said that there is a realistic possibility that his trial would have been deferred until the benefit of treatment took effect.

\section{B Mentally Disordered Patients}

Mr Cumming has now been assessed as being mentally disordered and he is also the subject of an in-patient compulsory treatment order under the Mental Health Act. This means Mr Cumming currently has: ${ }^{43}$

... an abnormal state of mind (whether of a continuous or intermittent nature), characterised by

delusions, or by disorders of mood or perception or volition or cognition, of such a degree that it -

41 J Brakel "Competency to stand trial: Rationalism, 'contextualism' and other modest theories" (2003) 21 Behav Sci Law 285 at 288.

$42 R v$ Pritchard, above $\mathrm{n} 5$, at 304.

43 Mental Health (Compulsory Assessment and Treatment) Act 1992, s 2. 
(a) poses a serious danger to the health or safety of [Mr Cumming] or of others; or

(b) seriously diminishes the capacity of [Mr Cumming] to take care of himself ...

In addition, a District Court Judge has decided it is necessary to make Mr Cumming the subject of a compulsory treatment order after having had regard to all the circumstances of his case ${ }^{44}$ and that Mr Cumming could not be treated adequately as an out-patient. ${ }^{45}$

An in-patient compulsory treatment order is the most restrictive order that can be made under the Mental Health Act other than orders that can be made in relation to defendants who are found not guilty by reason of insanity or who are unfit to stand trial. A patient is only made the subject of an in-patient compulsory treatment order after medical and judicial determinations that have the effect of detaining a patient and requiring them to undergo treatment. An in-patient compulsory treatment order is a remedy of last resort under the Mental Health Act which was passed to define: ${ }^{46}$

... the circumstances in which and the conditions under which persons may be subjected to compulsory psychiatric assessment and treatment, to define the rights of such persons and to provide better protection for those rights, and general rights.

Notwithstanding that Mr Cumming is currently the subject of an in-patient compulsory treatment order, he must be retried unless he is also found to be unfit to stand trial under the Act.

It is very difficult to conceive of circumstances in which a person who is the subject of an inpatient compulsory treatment order could realistically be fit to stand trial.

Even when Mr Cumming was not the subject of an in-patient compulsory treatment order the Supreme Court had little difficulty in concluding that at the time of his trial, Mr Cumming was suffering a mental disorder and that he must also have been unfit to stand trial at that time. The Supreme Court said: ${ }^{47}$

It is very clear to us that by reason of mental disorder Mr Cumming was under a disability or, in terms of the present legislation, unfit to stand trial. For that reason there has been a substantial miscarriage of justice.

However, the Act currently requires a further judicial assessment as to whether or not Mr Cumming is unfit to stand trial.

Mr Cumming's case illustrates a deficiency in the definition of "unfitness to stand trial" in s 4 of the Act which could be remedied by redefining "unfit to stand trial" so that the term is more closely

44 Mental Health (Compulsory Assessment and Treatment) Act 1992, s 27(3).

45 Section 28(2).

46 Mental Health (Compulsory Assessment and Treatment) Act 1992, preamble.

47 Cumming $v R$, above $\mathrm{n} 2$, at [21]. 
calibrated to medical and judicial decisions made under the Mental Health Act. This could be achieved if the definition of "unfit to stand trial" is amended so that those who are the subject of an in-patient compulsory treatment order under the Mental Health Act are automatically deemed to be unfit to stand trial for the duration of the in-patient compulsory treatment order.

\section{The Right to Self-representation}

The right of a defendant in a criminal trial to represent himself or herself is a relatively recent right. Although the Treason Act 1695 permitted a defendant in a treason trial to be represented and to put a defence, it was not until 1836 that those charged with a felony were entitled to advance a defence and to be represented. ${ }^{48}$ In New Zealand, the right of a defendant to be represented by counsel or to represent himself or herself is now contained in s 11 of the Criminal Procedure Act 2011. That provision can be traced through s 354 of the Crimes Act 1961, s 415 of the Crimes Act 1908 to s 391 of the Criminal Code 1893. The right of a defendant to represent himself or herself is also recognised in art 14(3)(d) of the International Covenant on Civil and Political Rights. ${ }^{49}$

The right to represent oneself in a criminal trial is closely linked to the right contained in $\mathrm{s} 25(\mathrm{e})$ of the NZBORA, which guarantees the right of a defendant to be present and to present a defence at his or her trial.

The United States Supreme Court has explained the right of a defendant to represent himself or herself "affirms the dignity and autonomy of [an] accused"50 and the right is underpinned by the fact that it is the defendant who suffers the consequences if his or her decision to represent himself or herself results in a conviction. ${ }^{51}$ Similarly, in $R v$ Swain Larmer CJ explained that in Canada: ${ }^{52}$

... the principles of fundamental justice contemplate an accusatorial and adversarial system of criminal justice which is founded on respect for the autonomy and dignity of human beings ... The principles of fundamental justice must also require that an accused person have the right to conduct his or her own defence.

In the United States the right of a defendant to represent himself or herself is qualified by the requirement that the defendant "knowingly and intelligently" foregoes the benefits of counsel. ${ }^{53} \mathrm{In}$ New Zealand the test is whether the defendant's decision to represent himself or herself is "a fully

48 Trial for Felony Act 1836 (UK) 6\&7 Will IV c 114.

49 International Covenant on Civil and Political Rights 999 UNTS 171 (opened for signature 16 December 1966, entered into force 1 July 2002).

50 McKaskle v Wiggins, above n 34, at 177.

51 Faretta v California 422 US 806 (1975).

$52 R v$ Swain, above n 34, at 504.

53 Faretta v California, above n 51. 
informed and deliberate one". ${ }^{54}$ Both tests can accommodate the approach taken in England and Wales, where it is recognised that a defendant's capacity to defend himself or herself is to be judged in relation to the decisions that are required to conduct a defence, and not on a general basis. ${ }^{55}$

Mr Cumming's insistence that he represent himself was probably driven by his delusional suspicions and persecutory obsessions. ${ }^{56}$ Ironically, it was only because he represented himself that his mental issues emerged with sufficient clarity that ultimately, clinicians and the Supreme Court were able to determine Mr Cumming was suffering from a mental disorder when he represented himself. Had Mr Cumming not dispensed with his lawyers it is conceivable his mental disorder would not have been able to be retrospectively diagnosed. Ideally, the outcome for Mr Cumming should not have depended on whether or not he was represented. However, his case does raise the possibility that some defendants in New Zealand are prosecuted and convicted in circumstances where they are suffering a mental disorder which is not able to be detected because of the effects of them being represented by counsel. This risk could be diminished if the test for determining if a defendant is unfit to stand trial is able to accommodate an assessment of a defendant's rationality.

\section{The Right to a Fair Trial}

Ultimately, the inviolate right to a defendant to receive a fair trial must prevail over all other considerations, including the rights of victims and society to have those charged with serious crimes tried and punished if convicted. It was this consideration which ultimately led the Supreme Court to quash Mr Cumming's convictions and order a new trial.

The right to a fair trial must also outweigh the right of a defendant to represent himself or herself, particularly in cases where a defendant's decision to dispense with counsel is driven by irrational views about the duties and responsibilities of lawyers. With the benefit of hindsight, $\mathrm{Mr}$ Cumming's decision to represent himself may have been so irrational and distorted by delusions that it was not a truly informed decision. In Mr Cumming's case, a more suitable solution at the outset may have been for him to have been ruled unfit to stand trial because his behaviour was so irrational. That outcome would have likely led to Mr Cumming being made a special patient and being provided with appropriate treatment many years before he underwent compulsory treatment. However, as this article has endeavoured to demonstrate, such an outcome would only be possible if the assessment of a defendant's fitness to stand trial incorporates a consideration of their rationality.

$54 \quad R v$ Miers, above n 33.

55 Masterman-Lister v Brutton \& Co [2003] 1 WLR 1511 at [57]; and Dunhill v Burgin [2014] UKSC 18, [2014] 1 WLR 933 at [13]

56 Cumming $v R$, above $\mathrm{n} 2$, at [18]. 


\section{CONCLUSION}

Since its passing, the Act and decisions under the Act have generated a number of challenges for judges, lawyers and medical professionals. Any review of the Act should include a reassessment of the law relating to a defendant's fitness to stand trial, to ensure the law more closely aligns with medical views about a defendant's mental competence. Until those steps are taken, cases such as those of Mr Cumming will continue to vex our legal system. 